(C) 1989 ISIJ

IIIIIIIIIIIIIIIII! 論 文

IIIIIIIIIIIIIIIII/

\section{導電型制振鋼板のスポット溶接性}

\author{
田中福輝 ${ }^{*} \cdot$ 佐藤始夫 ${ }^{*} \cdot$ 柚鳥善之 ${ }^{*} \cdot$ 郡田和彦 $*$
}

\title{
Spot Weldability of the Vibration Damping Steel Sheet
}

Yoshiki TANaKa, Motoo SATo, Yoshiyuki YUTORI and Kazuhiko KoORIDA

\begin{abstract}
Synopsis :
The improvement in spot weldability of a vibration damping steel sheet has been studied by mixing iron particles in the no-conductive resin film sandwiched by steel sheets. The influences of the particle size and the volume fraction has been investigated in relation to the occurrence of pinholes and micro-sparks. These defects are eliminated by using mixture of 3 volume percent particles where the particle diameter is 1.5 times the film thickness. The vibration damping steel sheet produced under these conditions shows good spot weldability without any bypass circuits, as well as high damping property.
\end{abstract}

Key words : composite materiail ; powder metallurgy ; weldability ; vibration damping steel sheet.

\section{1. 緒}

言

2 枚の鋼板の間に高分子の樹脂を挟持したタイプの制 振鋼板が内外の関心を集めている。この制振鋼板は騒音 源の板厚を厚くするなど他の騒音低減方法に比較して重 量増加することなく容易に騒音, 振動が低減できる゙ め急速に需要が伸びている. 自動車ではオイルパンなど のエンジン周り部品に古くから使用されているが，最近 溶接点数の多いパネル類にも適用が検討され始めた。し かし, 従来の制振鋼板は樹脂が電気絶縁体であるためス ポット溶接時にバイパス回路が必要となり，作業が煩雑 となるなどの問題がある．このため樹脂に導電性を付与 した通常の鋼板と同様にスポット溶接できる導電型制振 鋼板の要求が高まっている.

導電性を付与するには, グラファイトの微粉 ${ }^{2)}$ または 金属粉を樹脂に添加する方法があるが, 前者は多量の添 加が必要となり制振性能が低下する ${ }^{3)}$. 後者は少量の添 加で溶接が可能となる ${ }^{3445)}$ が, 添加量およびサイズな どの影響についての詳細な報告は少ない．また，いずれ も被溶接部位のなじみの良い平板試験片での調査であ る.しかし，実際のプレス成形部品にはそり，しわなど の寸法精度不良により溶接部位に隙間がある，さらにス ポット溶接ガンのすべりによる加圧力低下などの不具合 もあるため溶接条件は平板試験片の場合に比較して厳し く，その溶接挙動も異なると考えられる.

本報告では，導電型制振鋼板（以下制振鋼板と記す）
の開発を目的として，表皮鋼板（以下鋼板と記す）と同 一組成の鉄粉を導電物質として用い，スポット溶接性に およほすす添加量および粒径の影響について，まず平板試 験片を用いて基本的に調査し，つぎに実成形品の溶接部 位をシミュレートしたすきま付き試験片で検討した結果 を述べる。

\section{2. 供試材およびスポット溶接条件}

\section{$2 \cdot 1$ 供試材}

制振鋼板の表皮は $0.4 \mathrm{~mm}$ 厚さの低炭素 $\mathrm{Al}$ キルド鋼 板とし, 樹脂には常温域での制振性のすぐれた $51 \mu \mathrm{m}$ 厚さのポリオレフィン系を用いた。還元処理した $0.003 \% \mathrm{C}-0.18 \% \mathrm{Mn}-0.014 \% \mathrm{P}-0.014 \% \mathrm{~S}$ の水アトマイズ 鉄粉（Photo. 1）をJIS-Z8801 の規定にしたがって2 ランク異なるメッシュの範囲の大きさに筛い分け整粒と した。これを樹脂に混練して均一分散させたフィルム状 とし， 2 枚の鋼板に挟んで実機で接着して制振鋼板とし た.

成形性の指標となる樹脂の剪断引張強度は JIS-

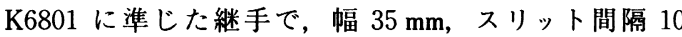
$\mathrm{mm}$ の形状で測定した。 また制振性能は幅 $20 \mathrm{~mm}$ 長さ $200 \mathrm{~mm}$ の試験片を用い，共振法で周波数を変化させ共 振曲線の半值幅から損失係数 $\eta$ を求めて評価した.

\section{$2 \cdot 2$ スポット溶接条件}

平板試験片では $30 \mathrm{~mm} \times 100 \mathrm{~mm}$ の制振鋼板を同一サ イズの $0.8 \mathrm{~mm}$ 厚さの冷延鋼板と $30 \mathrm{~mm}$ 重ね合わせ, 


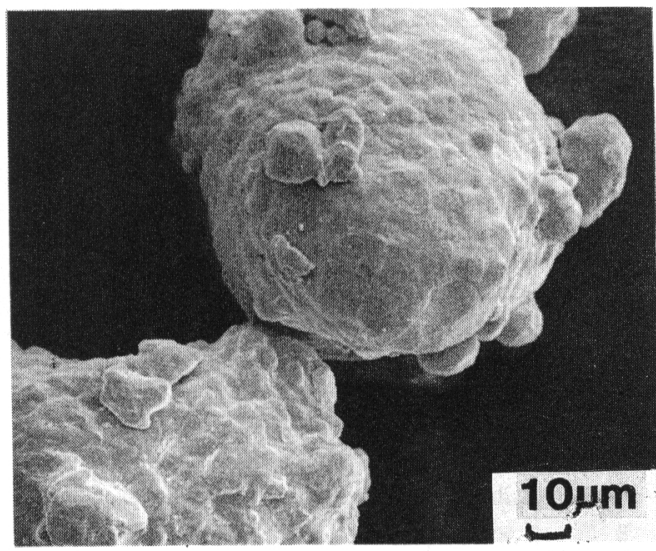

Photo. 1. Typical microphotograph of the atomized iron particles.

Table 1. Welding conditions.

\begin{tabular}{l|l}
\hline Electrode & Dome type tip $6 \mathrm{~mm} \phi \mathrm{Cu}-\mathrm{Cr}$ \\
Electorode force & $200 \mathrm{kgf}, 150 \mathrm{kgf}$ \\
Welding current & $8 \mathrm{kA}, 10 \mathrm{kA}$ \\
Welding time & 12 cycles $/ 60 \mathrm{~Hz}$ \\
\hline
\end{tabular}

その中心に Table 1 の条件でスポット溶接を行った. また，実成形品ではプレス時のねじれ，そりなどのため 溶接部位にすきまが発生し，なじみの良い試験片での溶 接挙動とは異なる。この厳しい条件下での溶接性を評価 するために Fig. 1 のすきま付試験片（スペーサ：軟鋼 板）を用い，端部からの距離 $(X)$ を変化させて溶接し た。

溶接機は $50 \mathrm{kVA}$ の定置式ダイレクトスポットタイプ で, 制御器には電流の立ち上がりの早い定電流制御方式 を用いた。

\section{3. 結果および考察}

\section{$3 \cdot 1$ 平板試験片でのスポット溶接性}

\section{$3 \cdot 1 \cdot 1$ 導電性におよぼす鉄粉粒径の影響}

樹脂中の鉄粉の添加量を $3.5 \mathrm{vol} \%$ と一定にし，粒径 を変えた制振鋼板を加圧力 $200 \mathrm{kgf}$, 溶接電流 $10 \mathrm{kA}$ で スポット溶接した場合の不良発生率を Fig. 2 に示す. また同図には剪断引張強度と $50^{\circ} \mathrm{C} \cdot 1000 \mathrm{~Hz}$ での制振性 の変化を併せて示す. 篩い分けられた鉄粉を球形と仮定 し, その粒径の中央值 $D$ (以下鉄粉粒径と記す) と樹 脂膜厚さ $t$ の比で整理すると, $D / t$ の值が 1.2 よりも 小さい場合は，鋼板に図中の断面図に示すような穴開 き6) ( A夕イプ欠陥) または焼け, 未通電などの不良が

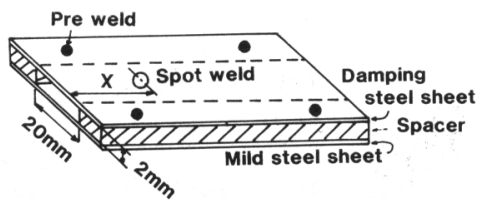

Spacer : Mild steel

Fig. 1. Simulated assemble panel with a gap.

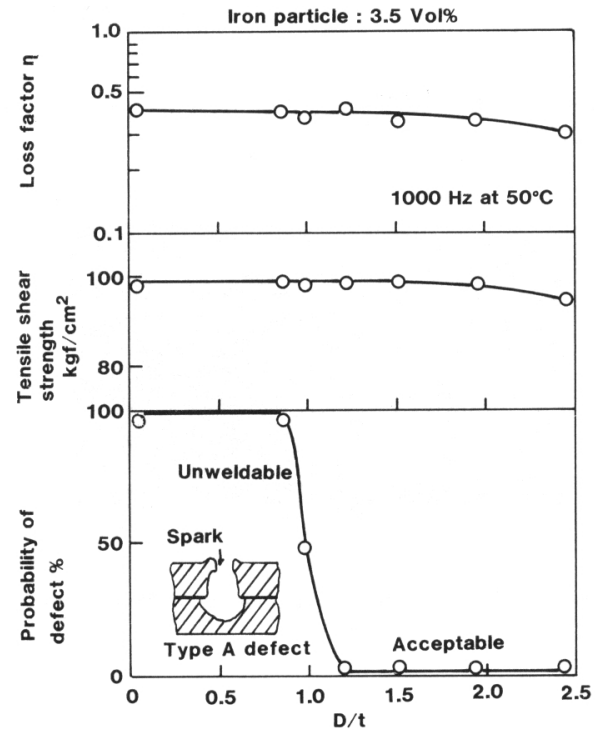

$D$ : Diameter of iron particle Welding current : $10 \mathrm{kA}$ $t$ : Resin layer thickness Electrode force : $200 \mathrm{kgf}$

Fig. 2. Effects of $D / t$ on the type A defect, tensile shear strength and loss factor.

発生し， $D / t$ が 0.9 で不良率 $100 \%$ となる. $D / t$ が 1.2 より大きくなると,このような不良現象は認められない.

$D / t$ が 0.9 と 1.2 の場合の鉄粉粒径はそれぞれ 37 $53 \mu \mathrm{m}$ (中央值 : $45 \mu \mathrm{m}$ ) 抢よび $54 \sim 73 \mu \mathrm{m}$ (中央值 $63.5 \mu \mathrm{m})$ である。これから明らかなように，溶接不良 を防止するためには，樹脂膜厚よりも大きな鉄粉を添加 し，樹脂を挟む鋼板間に十分な数の短絡回路（内部短絡 回路）を確保する必要がある。樹脂中の鉄粉の状態を Photo. 2 に示す. 極低炭素の鉄粉は樹脂と鋼板接着時 の高いロール加圧力で大きく塑性変形し，また鋼板も若 干変形して书り再者には十分な金属接触が認められ，内 部短絡回路が得られていることが分かる.

樹脂膜厚よりも大きな鉄粉を添加した場合，樹脂と鋼 板の接触面積の減少により制振性能，およびプレス成形 性に影響する剪断引張強度の低下が懸念される。しかし $D / t$ が 1.9 以下であればほとんど影響は認められない. 


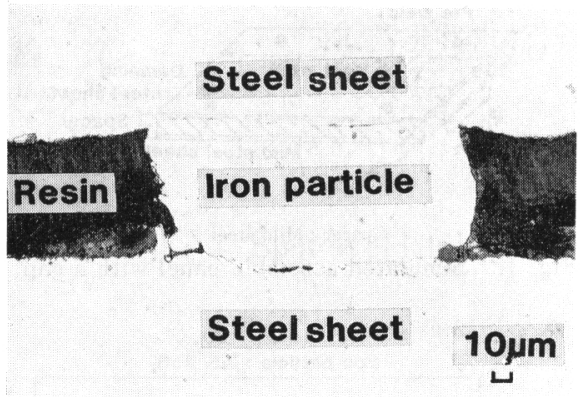

Photo. 2. Microphotograph of iron particle filled in resin layer.

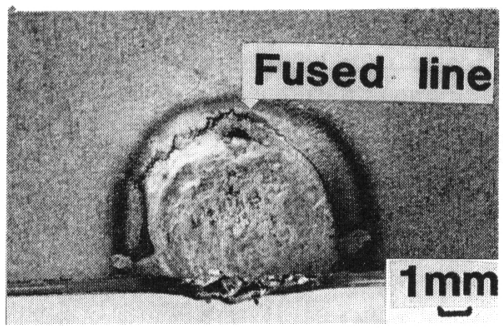

Photo. 3. Type B defect observed around the indentation.

\section{$3 \cdot 1 \cdot 2$ 鉄粉の添加量の影響}

制振鋼板の溶接性に影響する他の因子として鉄粉の添 加量が考えられる．制振性が低下しない最大の鉄粉粒 $(D / t: 1.9)$ を用いた場合の添加量の影響を Fig. 3 に示 す.同図には剪断引張強度抢よび制振性を併せて示した。 鉄粉の添加量を増すと溶接不良は減少し, $2.0 \mathrm{vol} \%$ 以 上で発生しなくなる。また，制振性㧍よび剪断引張強度 とも 4 vol\%の添加までは低下が認められない.

以上の結果から，溶接部のなじみの良い平板試験片で 制振性能および接着強度を低下させずに溶接性の良好な 制振鋼板を得るには，樹脂膜厚よりも大きい粒径の鉄粉 を鋼板の全域に均一に分散させる，すなわち電極下揖よ びその周井で十分な内部短絡回路を確保する必要があ る.

\section{$3 \cdot 2$ すきま付き試験片でのスポット溶接性}

$3 \cdot 2 \cdot 1$ すきま付き試験片でのスポット溶接不良

実成形品で見られる溶接条件下での制振鋼板のスポッ 卜溶接性を調べるため，Fig. 1 のすきま付き試験片を用 いた。最も厳しい溶接条件のシミュレートとして加圧力 $150 \mathrm{kgf}$ と低くしかつ, 試験片の端部に電極先端面積の 1/2 が接する (Fig. 1: $X=0)$ 条件を用いた. その結果,

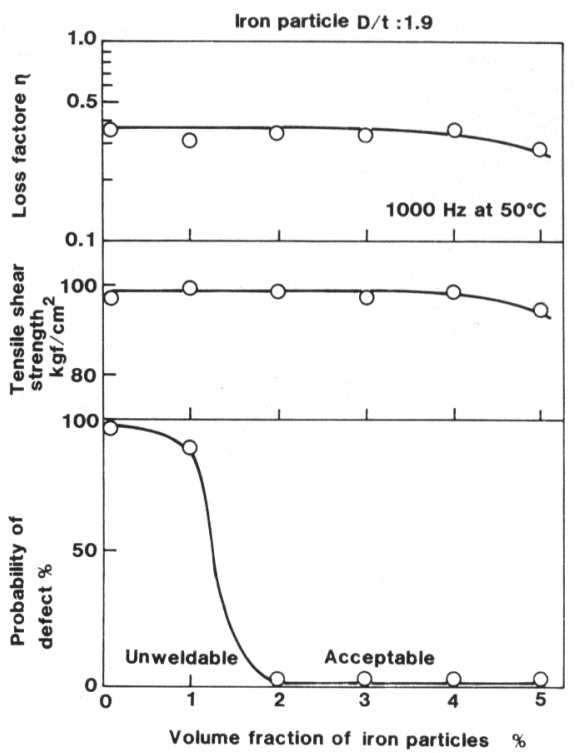

Welding current : $10 \mathrm{kA}$ Electrode force : $200 \mathrm{kgf}$

Fig. 3. Effects of volume fraction of iron particles on the type A defect, tensile shear strength and loss factor.

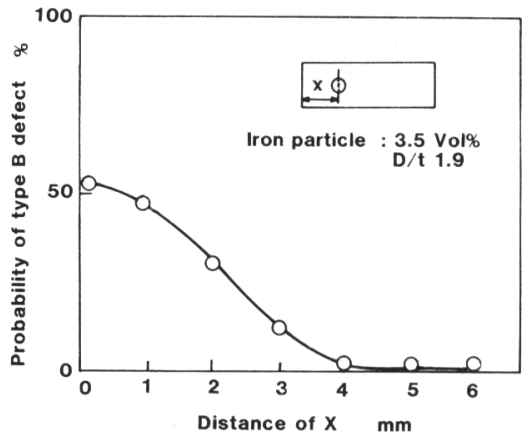

Welding current : $10 \mathrm{kA}$ Electrode force : $150 \mathrm{kgf}$

Fig. 4. Effect of welding point on the type B defect.

Photo. 3 に示すように, 制振鋼板の電極と接した側の 鋼板の電極周辺部が溶融する欠䧩（以下Bタイプ久陥と 記す）が発生した。

B夕イプ欠陥は, フランジのコーナー部にスポット溶 接した場合にも認められる6)ことから，この久陷の発生 は溶接位置にも影響されると考えられる。 $D / t$ が 1.9 で添加量を 3.5 vol\% とした制振鋼板を用いて，すきま 付き試験片で端部からの距離を变えて溶接し，B夕イプ 欠陷発生率を調査した (Fig. 4). 不良は電極先端 $(6 \mathrm{~mm} \phi)$ 


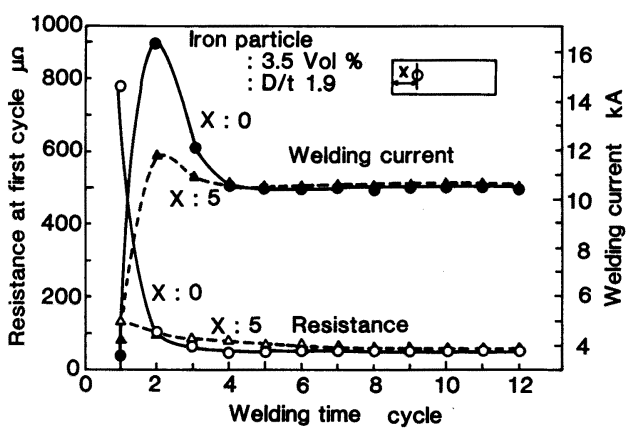

Electrode force : $150 \mathrm{kgf}$

Fig. 5. Changes of resistance and welding current with welding time.

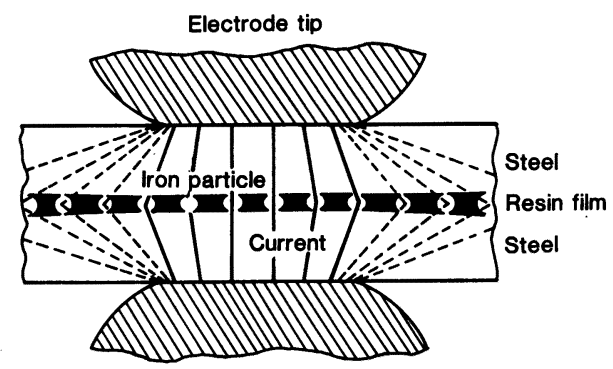

Electrode tip

Fig. 6. Schematic illustration of current path at initial stage of welding.

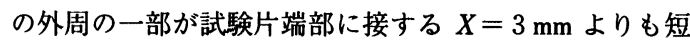
い距離で発生しており, 溶接部がフランジ端部に近いほ ど発生率が高いことが分かる.

\section{$3 \cdot 2 \cdot 2$ 電極周辺部の溶融破断の発生原因}

Bタイプ欠陥の発生原因を明確にするため, 通電中の 各サイクルごとの電極間抵抗および溶接電流を測定し た. Fig. 5 に不良が発生する場合 $(X=0 \mathrm{~mm})$ と, 発 生しない場合 $(X=5 \mathrm{~mm})$ のそれらの代表例を示す. フランジ端部の溶接では 1 サイクル目の抵抗値がフラン ジ内部の場合よりも約 7 倍と極めて高く，また電流值も 2 サイクル目で $16 \mathrm{kA}$ と軟鋼板の溶着限界 ${ }^{7}$ に近い高 電流となっている. さらに，B夕イプ欠陥は 3 サイクル で通電を停止したサンプルにすでに存在し，また不良発 生に伴う溶接中の電極間電圧波形の乱れは $1.0 \sim 2.5$ サ イクル間で認められた。

以上の結果から B タイプ欠陥の発生原因はつぎのよう に考えられる.まず制振鋼板内の電流パス回路について 見ると, $D / t$ が 1.9 と大きな鉄粉では前述のように樹 脂を挟む鋼板間が鉄粉により短絡されており，通電初期

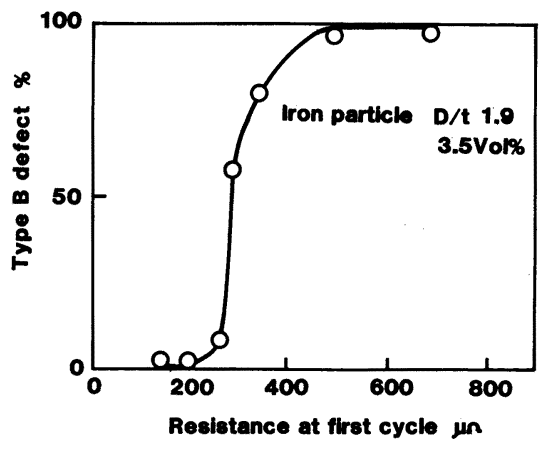

Welding current : $10 \mathrm{kA}$ Electrode force : $150 \mathrm{kgf}$

Fig. 7. Relationship between resistance at first cycle and type B defect.

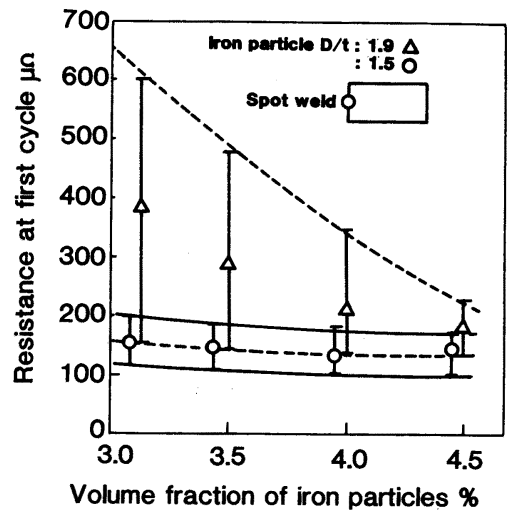

Fig. 8. Effects of volume fraction and size of iron particles on the resistance at first cycle.

には Fig. 6 の模式図に示す電流分布になっている. フ ランジ内部の溶接では, 同図のように電極周辺部にも内 部短絡回路が確保されるため 1 サイクル目の抵抗は低い が, 端部の溶接ではこの回路の数が減少し, 抵抗が高く なる.このため端部溶接では定電流機能により 2 サイク ル目が大電流となるが，この時点ではまだ鋼板同士に大 電流を流すための十分な通電経路がなく, 分流電流密度 が過大となり電極周辺部が溶融し破断する.このことか ら B タイプの欠陥は 1 サイクル目の抵抗値と相関がある と考えられる.

抵抗値の異なる制振龬板を用いて調査したB夕イプの 不良発生率を Fig. 7 に示す．両者には相関があり，1 サイクル目の抵抗值が約 $250 \mu \Omega$ よりも高くなると不良 が発生することが分かる. したがって，これよりも低い 抵抗値にすることにより B タイプ欠陥の発生を防止でき ると考えられる. 
$3 \cdot 2 \cdot 3$ 電極周辺部の溶融破断におよほす鉄粉粒径お よび添加量の影響

1 サイクル目の抵抗值を低くするためには，鉄粉の添 加量を増やすか, または粒径を大きくするなどにより電 極直下およびその周辺で十分な内部短絡回路を確保する 必要がある．制振性などを低下させない範囲で添加量, 粒径を変化させてフランジ端部 $(X=0)$ に溶接した場 合の 1 サイクル目の抵抗値を調査した（Fig. 8). 図中 の曲線の幅は $N$ 数 50 の上下限值を示す.

$D / t$ が 1.9 の場合は添加量を増すと抵抗の下限值は ほとんど変化しないが上限値が急激に低下し，このため 4.5 vol\% ではBタイプ欠陥が発生しなくなる．一方， $D / t$ が 1.5 の場合はばらつきが小さく，いずれの添加

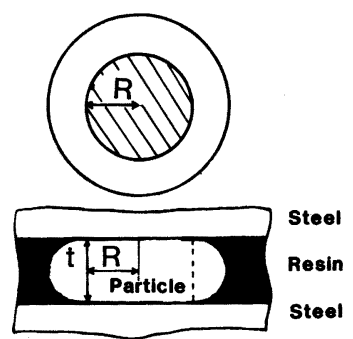

Upper : Plain view Lower: Cross sectional view

$R$ : Radius of contacted area $t$ : Thickness of iron particle

Fig. 9. A model of an iron particle between steel sheets.

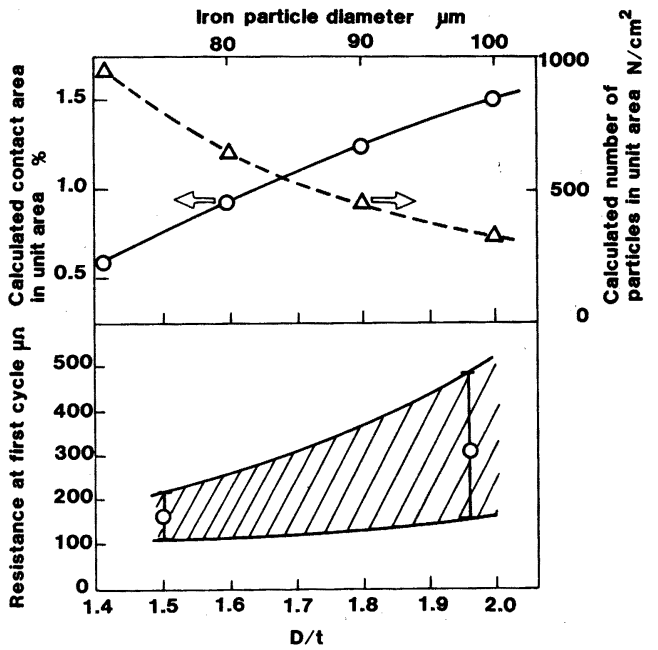

Iron particle : 3.5 vol\%

Fig. 10. Changes of resistance at first cycle, calculated contact area between iron particles and steel sheeet and numbers of iron particles in unit area.
量においても約 $200 \mu \Omega$ 以下の低い抵抗值でありB夕イ プ欠陥は発生しない.この結果から 1 サイクル目の抵抗 值は鉄粉の添加量よりも，粒径に大きく影響されること が分かる.

粒径の影響を明確にするため鉄粉は球形とし，樹脂中 で円板状に変形した鉄粉と鋼板の界面 (Fig. 9 の斜線部) はすべて接触していると仮定して，その単位面積あたり の総接触面積率 $S(\%)$ ，および鉄粉の個数 $N$ を次式办 ら求めた.

$$
\begin{aligned}
& 4 \pi r^{3} / 3=\pi t\left(t^{2} / 6+\pi t R / 4+R^{2}\right) \\
& 4 \pi r^{3} / 3 \cdot N=V_{f} \cdot t / 100 \\
& S=\pi R^{2} \cdot N \cdot 100
\end{aligned}
$$

ここで $R$ は鉄粉と鋼板の接触面の半径 $(\mathrm{cm})$, $r$ は変形前の鉄粉の半径 $(\mathrm{cm})$, $t$ は樹脂厚さ $(\mathrm{cm})$, $V_{f}$ は樹脂中の鉄粉の添加量（\%) を示す.

この計算値を $D / t$ で整理し 1 サイクル目の抵抗変化と 併せて Fig. 10 に示す. $D / t$ が増すと共に接触面積率 $S$ は増加するにもかかわらず，抵抗値は逆に増加している. この抵抗值の増加は鉄粉個数の減少, すなわち内部短絡 回路数の減少と対応している.

この原因を明確にするために鉄粉と鋼板の接触状態を 調查した結果，両界面には樹脂が部分的に残存しており 通電に有効な接触面積が減少していることが分かった. この残存状態は Photo. 2 でも観察され鉄粉と鋼板の下 方部の界面で黒く見える部分がそれである. 樹脂の残存 は鉄粉および鋼板表面の凹凸などにより，樹脂がその界 面から十分に排出されないためで，鉄粉の粒径が大きく なるほどその残存量は増すと考えられる.

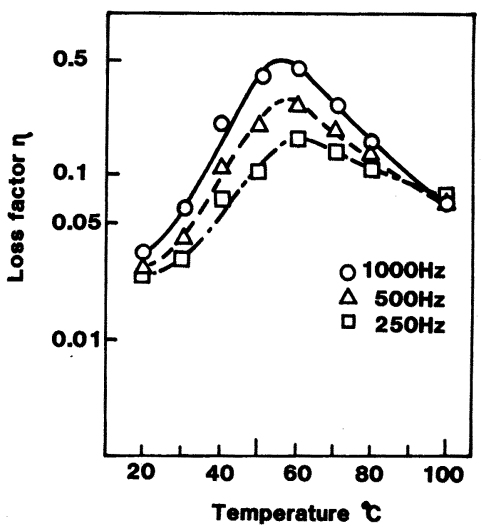

Fig. 11. Changes of loss factor with temperature in typically developed weldable vibration damping steel sheet. 


\section{Damping steel sheet $X$ Mild steel sheet}
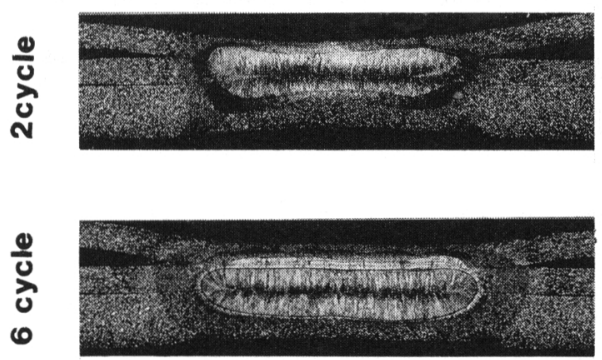

Mild steel sheets $\left(0.4^{t} \times 2\right)$

$X$ Mild steel sheet
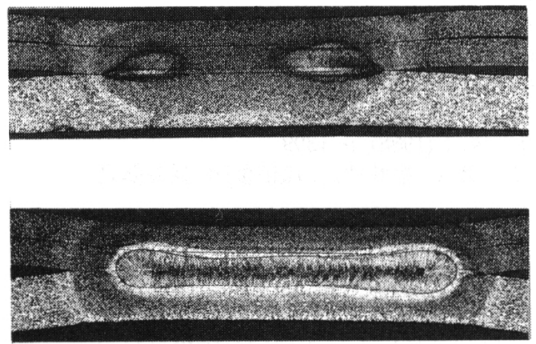

$1 \mathrm{~mm}$

Welding current : $8 \mathrm{kA}$ Electrode force : $200 \mathrm{kgf}$

Photo. 4. Typical microphtographs of spot welds.

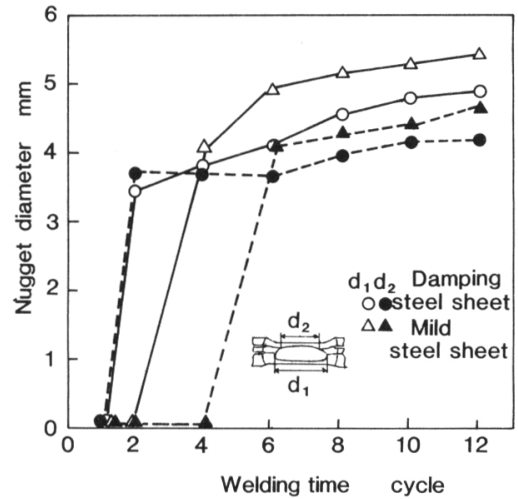

Welding current : $8 \mathrm{kA} \quad$ Electrode force : $200 \mathrm{kgf}$

Fig. 12. Changes of nugget diameter with welding time in typically developed weldable vibration damping steel sheet and usual mild steel sheets.

このことから，Fig. 10 で $D / t$ が大きくなると 1 サイ クル目の抵抗が高くなることはつぎのように考えられ る. 鉄粉粒径が大きくなっても 1 個あたりの有効接触面 積は，鉄粉と鋼板の界面での樹脂の残存により理想的な 状態の場合よりもかなり小さい。一方, 添加量が一定で あるため粒径が大きくなると鉄粉の個数は低下する。し たがって，両者の積で決まる通電に有効な接触面積率は この個数低下の影響を強く受け， D/ $t$ が小さい場合より も減少し, 抵抗は高くなる。

\section{$3 \cdot 3$ 制振鋼板の制振性とスポット溶接き性}

実成形品でのなじみ不良部位を想定したすきま付き試 験片でのBタイプ欠陥の発生を防止した常温用の制振鋼 板の制振性を Fig. 11 に示す。いずれの周波数において

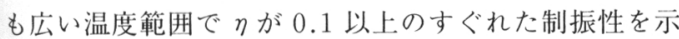

している.

この制振鋼板のスポット溶接性を，2枚の鋼板間に樹 脂を挟まない同板厚鋼板の組合せの場合と併せて Photo. 4 および Fig. 12 に示す。溶接は平板試験片の中 央部に散りの発生しない条件で行った。両者は通電初期 の発熱状態が異なり，制振鋼板のナゲット生成が早くな る.これは樹脂の存在により通電径が制限され, その界 面での発熱が高くなったためと考えられる。しかし，6 サイクル以降では両者のナゲット生成挙動はほぼ同等と なる．また，制振鋼板で問題となる樹脂が存在する界面 でのナゲット径 $\left(d_{2}\right)$ も確保されている.

\section{4. 結言}

導電型制振鋼板の金属フィラーとして鉄粉を用い, ス ポット溶接におよぼすその粒径, 添加量などの影響につ いて平板およびすきま付き試験片で検討した結果以下の 知見を得た。

(1)通常の鋼板と同様なスポット溶接性を得るために は，鉄粉の粒径 $(D)$ を樹脂膜厚 $(t)$ よりも大きくし, 電極直下およびその周辺部でも表皮鋼板同士の短絡回路 を十分に確保することが必要である.

(2)実成形品での厳しい溶接をシミュレートしたすき ま付き試験片の，端部溶接時に発生するナゲット周辺の 溶融破断防止には，単位面積あたりの鉄粉個数を増加さ せることが重要である。このために鉄粉粒径を樹脂膜厚 よりもわずかに大きくし，制振特性などを低下させない 範囲で添加量を多くすることが有効である.

( 3 )( 2 )を満たす導電型制振鋼板は通常の鋼板と同様 にスポット溶接ができ，制振性能もすぐれている. 


\section{文献}

1 ) 郡田和彦: 第 $106 \cdot 107$ 回西山記念技術講座 (日本鉄鋼協会 編) (1985), p. 265

2 ) $Y$. Matumoto, $M$. Shinozaki and $K$. Tsunoyama:

Proceedings of Resistance Welding and Related Welding Processes, Osaka (1986 年 7 月), p. 98

3 ) 江島瑞男, 遠藤 紘, 座間芳正, 松田良一, 概原洋史:

材料とプロセス, 1 (1988), p. 1399

4 ) 中西睦夫, 高 隆夫, 福井清之, 塩田俊明, 長井弘之:
鉄と龬, 73 (1987), S1504

5 ) 西本昭彦, 渡辺裕吉, 藤井康司, 樺沢真事, 松田恭典: 日本鋼管技報 (1988) 121, p. 9

6 ) 吉田英一, 三浦俊勝, 田中福輝: 溶接学会論文集, 5 (1987), p. 171

7 ) 田中福輝, 野村伸吾, 小久保一郎: 鉄と鋼, 68 (1984), p. 1437 